MARKO MATULIN, Ph.D. candidate

E-mail: marko.matulin@fpz.hr

ŠTEFICA MRVELJ, Ph.D.

E-mail: mrveljs@fpz.hr

NIKO JELUŠIĆ, Ph.D.

E-mail: niko.jelusic@fpz.hr

University of Zagreb,

Faculty of Transport and Traffic Sciences

Vukelićeva 4, 10000 Zagreb, Croatia
Traffic in the Cities

Original Scientific Paper

Accepted: Feb. 14, 2011

Approved: July 6. 2011

\title{
TWO-LEVEL EVALUATION OF PUBLIC TRANSPORT PERFORMANCES
}

\begin{abstract}
The focus of this paper is evaluation of public transport (PT) performances. For this purpose the focus is on quantitative performance attributes of tramway network and two levels of the evaluation analysis are defined - the micro and macro level analysis. The two-level evaluation analysis can be used to solve the problem of ambiguity in conclusions about PT performances. The ambiguity appears when the set of collected data is incomplete, misinterpreted, partially analyzed or when some background impacts are neglected. For each level of analysis a set of performance indicators is defined and their mathematical formulations are presented. The selection of indicators is based on the analysis of ex pected events on the PT vehicle's itinerary. The applied data collection methodology, necessary for testing of proposed evaluation approach, is described and the results are presented and discussed. It has been found that for a specific case the two-level evaluation analysis can be important for the control of PT performances and transport planning.
\end{abstract}

\section{KEY WORDS}

evaluation, public transport performance, micro and macro level analysis, quality of service

\section{INTRODUCTION}

Public transport (PT) is generally perceived as a public service of great importance. It is a service that meets the needs of mobile citizens and contributes to overall quality of life and sustainability. PT system itself can be described as a system with complex relations between transport infrastructure, transport demand, economy, politics, land-use planning and, more recently, marketing. These relations define the development of PT through its accessibility, availability, utilization and, ultimately, through its performances that are in the focus of this paper. Effective performance evaluation is an important means of promoting the operation efficiency and service quality of urban public transport systems, [1-2]. While reviewing the literature it was found that PT performances are often ill-defined or that different authors make different interpretations of what PT performances are and how they are measured or calculated. The boundary between PT performance and PT quality of service has proven to be vague as well.

Egmond et al. in [3] defined four levels of PT performances (external, strategic, tactical and operational). The first level performances are focused on population attributes, population density and distribution, thus, they do not fall under the competence of an urban mass transit authority. Strategic level is referred to the political interest and regulations. Tactical level performances are oriented toward organizational and financial framework analysis, while operational level deals with the accessibility of different PT modes, intermodality, marketing and information. Authors in [4] analyze the efficiency of different German public transport companies by using nonparametric comparative efficiency analysis. The proposed model for efficiency analysis comprises two inputs: labour (number of fulltime and part-time workers) and capital (number of buses); and one output: seat kilometres or bus kilometres. Their research deals with the supply aspect, specifically, with the evaluation of economic efficiency of PT companies. Another PT performance evaluation through economic indicators can be found in [5]. The authors are concentrated on detecting the common bus service problems and the study of PT quality of service and coverage. The presented indicators of the PT performance are capacity utilization, traffic revenue and operating cost per passenger-kilometre. Other examples of evaluation of PT performances through financial analysis can be found in [6-8].

Thompson and Schofield in [9] devote higher importance to the user perspective of PT performance 
and they state that "hardcore" performances are good indicator for service provider but "true" performance can only be evaluated with customer satisfaction survey. Similarly, Kordupleski et al. in [10] elaborate that the "internal" quality of a public transport service can be evaluated on the basis of whether "hard" performance targets (often set by the service provider) have been met, but the evaluation of "true" quality relies on eliciting customer perceptions of system performance and it is considered more difficult to measure. Further distinction between different aspects of PT performances is given by Harrison et al. in [11] who define "hard" quality attributes as those which are more quantifiable (e.g. access time) and "soft" quality attributes as "non-journey time attributes" such as information provision, staff attitude and satisfaction. After extensively reviewing the literature on measuring PT performance, Pullen in [12] concluded that there was a distinct lack of standardisation in the definition of the attributes which comprise public transport performance, and argued for improved definition and clarification of these attributes.

In their research Prioni and Hensher grouped bus performance attributes into six quality dimensions: accessing the bus stop, wait time, trip, vehicle, driver and information, [13]. Another attempt in categorization of PT performance indicators is made in [9] where several attributes are confirmed as being important measures of performance (travel time and fare, attributes pertaining to customer care, reliability, punctuality, information provision, cleanliness, comfort and security). In 2002, EU deployed a standard for certification of public transport system performances (EN13816) which categorizes performance indicators (qualitative and quantitative) into 8 categories: availability (network, operation time, reliability), access (interfaces, ticketing), information (travel information), time (travel time, punctuality, regularity), customer service (availability of personal, competence, assistance), comfort (space, driving), safety (criminal attacks, accidents) and environment, [14]. Yeh et al. also combines the qualitative and quantitative performance attributes while developing a fuzzy multi-criteria analysis for the performance evaluation of bus companies, [15].

This brief literature overview serves for the purpose of showing how different interpretations of PT performance can lead toward inconsistency in evaluation approach and definition of performance indicators. This implies that a set of indicators is needed to describe PT performance in qualitative and quantitative manner.

In order to solve the problem of connecting qualitative and quantitative indicators for describing the quality of service for any PT system, an analogy is drawn with telecommunications system. This is because definitions of indicators and their relations for this kind of system are much better investigated. In general, two sets of indicators can be defined when evaluating the PT system:

1. Performance indicators (or "hard" indicators) - this set of indicators describes the performance of PT in a quantitative manner (e.g. operational speed, dwell time, service intervals, number of accidents, punctuality, etc.)

2. Quality of service indicators (or "soft" indicators) this set of indicators is used for surveying the user opinion about specific aspects of the PT service and describing it in a qualitative manner (e.g. satisfaction about punctuality, travel time, safety, ticket price, comfort, company image, etc.).

Comprehensive evaluation of PT system includes both aspects - quantitative and qualitative. In the analysis of the PT performance the values of indicators in both sets can be monetised, thus, financial (economic) performances can be derived. The evaluation of PT performances in this paper comprises only quantitative attributes which can be used to describe a vehicle journey. The list of exploitation parameters found in [16] has been expanded here and each parameter (indicator) has been committed to a specific level of analysis. The qualitative evaluation and economic evaluation of PT performances is not within the scope of this paper.

The paper is structured as follows: the next section defines the two-level evaluation approach, performance indicators and their mathematical formulation. Section 3 describes data collection methodology that was used to collect the data necessary for testing the evaluation approach. Section 4 introduces the results of two-level evaluation of PT performances. The usability of the proposed approach is discussed in Section 5, and Section 6 contains the conclusion.

\section{DEFINING THE EVALUATION APPROACH}

\subsection{Vulnerability of PT performances}

By observing PT infrastructure in different cities it can be seen that there are numerous examples of transport infrastructure sharing, i.e. mixed traffic conditions are present. This is due to the structure of the cities, space limitations, costs of building new infrastructure (e.g. underground systems) and other factors which are outside the PT operators' influence. In these circumstances usually PT operator is the one responsible for finding a balance between the desired quality of PT service and the real PT performances in a specific time period. This requires the defining of schedules for PT vehicles and determining the necessary number of vehicles in operation for a given period of time, [1617]. The significance of this task can be highlighted by the fact that any discrepancy between the delivered performances and the expected service quality by the 


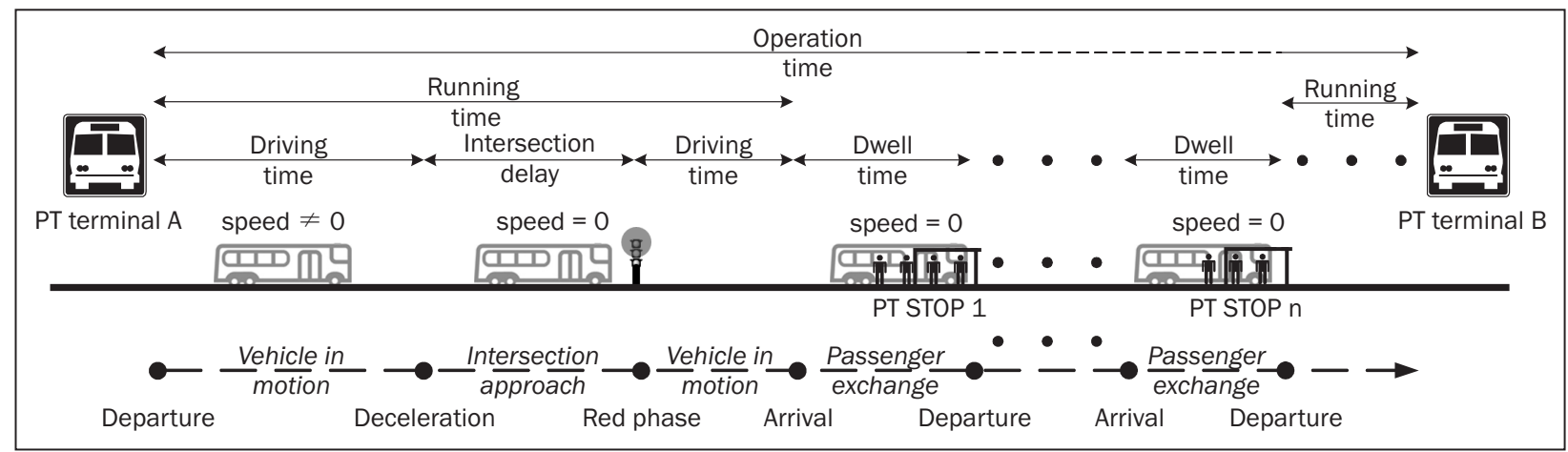

Figure 1 - Operation time decomposition

users can cause a wide set of negative impacts (e.g. on modal split).

The main source of vulnerability of PT performances lies in the concept of transport infrastructure sharing. When travelling on their PT lines, PT vehicles often share the infrastructure with individual transport, sometimes partially and other times along the full length of a specific PT line. Sun et al. showed that in such environment complex interactions are present between PT vehicles and the general traffic vehicles, [18]. In his research of urban traffic flows Zhu found that ordinary two-lane traffic suppresses public transportation causing performance degradation, [19]. The problem occurs during the periods of high traffic flows, when queues of cars can be formed in front of intersections, which then block the pathway of PT vehicles. In this case, even positive impacts of giving priority to PT vehicles at signalised intersections can be easily cancelled out. The pathway of PT vehicles can also be blocked by traffic accidents or traffic offenses of car drivers, which results in further performance deterioration.

When conducting a comprehensive analysis of PT performances, it may be recognized that the number of intersections and the design of signalling plans, the number of PT stops and passengers can affect the final results. In their extensive research about PT demand and performances, Balcombe et al. make it clear that in practice these factors cannot be treated either in isolation from each other or in isolation from many other direct and indirect (background) influences on public transport, [20].

For the purpose of evaluating PT performances a set of performance indicators has been defined. With the proposed evaluation approach different levels of analysis (micro and macro) can be performed and different impacts can be detected.

\subsection{Two-level evaluation and performance indicators}

On a single journey of a PT vehicle there are two terminals (origin terminal $\mathrm{A}$ and destination terminal
B) and a finite number of PT stops in-between. Due to the dynamic properties of traffic flow and due to various above described impacts, a PT vehicle can encounter different events on its itinerary. These events can cause decrease in average vehicle speed, increase of travel time and delay etc.

Two levels of PT performance analysis are defined now. Let the macro level analysis be the analysis of PT performances for the entire PT line and the micro level analysis the analysis of PT performances on specific intersection or segment of a line. If the PT performances are evaluated only at end points of the vehicle itinerary (i.e. at terminals) and if the conclusions are made only on that macro level, important influences on PT performances on the micro level will be neglected. In order to be able to analyze the data on both levels the operation time decomposition has been introduced as depicted in Figure 1. At the bottom of Figure 1 there is a list of expected events on the PT vehicle's itinerary and in the upper part there is a specification of specific operation time segments in relation to those events.

Apart from the presented indicators from Figure 1, two more indicators, which can be derived, are described: speed per segment and operating speed (see Table 1). Note that the running time indicator can also be related to the users' perception about their travel time between the adjacent PT stops.

Operation time decomposition enables detection of changes of each described time interval per individual segment of the PT line. With this approach more focused analyses can be carried out on specific segments of the PT line, [22-23].

\subsection{Mathematical formulations of performance indicators}

The mathematical formulations for the group of indicators defined in Table 1 are presented. According to definition provided in [16] and [21], the total vehicle operation time $\left(T_{o p}\right)$ is given by:

$T_{o p}=T_{d w}+T_{r t}$ 
Table 1 - Indicator description

\begin{tabular}{||c|l|l||}
\hline Level & \multicolumn{1}{|c|}{ Indicator } & \multicolumn{1}{c||}{ Description } \\
\hline \hline \multirow{3}{*}{ Macro } & Operation time & $\begin{array}{l}\text { The time that elapses from the departure of a PT vehicle from a ter- } \\
\text { minal to the arrival at the other terminal on the line. }\end{array}$ \\
\cline { 2 - 3 } & Operating speed & $\begin{array}{l}\text { The average journey speed of PT vehicles between an origin and a destina- } \\
\text { tion terminal, including any delay arisen in the course of the journey. }\end{array}$ \\
\hline \multirow{4}{*}{ Micro } & Dwell time & $\begin{array}{l}\text { The time which a vehicle spends at a PT stop due to passenger exchange. The } \\
\text { time needed for opening and closing the doors is also a part of dwell time. }\end{array}$ \\
\cline { 2 - 4 } & Intersection delay & $\begin{array}{l}\text { The time that elapses from the arrival of a PT vehicle at an inter- } \\
\text { section approach to its passing through the intersection. }\end{array}$ \\
\cline { 2 - 3 } & Speed per segment & $\begin{array}{l}\text { Vehicle speed for predefined segments of the line (a segment rep- } \\
\text { resents a part of PT line between two adjacent PT stops). }\end{array}$ \\
\cline { 2 - 3 } & Running time & $\begin{array}{l}\text { The time that elapses from the departure of a PT vehicle from a } \\
\text { stop to the arrival of a PT vehicle at the adjacent stop. }\end{array}$ \\
\cline { 2 - 3 } & Driving time & The time that a vehicle spends in motion. \\
\hline \hline
\end{tabular}

Source: [21]

where $T_{d w}$ is the total time spent at PT stops and $T_{r t}$ is the total time spent on running between PT stops by the PT vehicle on a journey between two terminals. For a known length of a PT line ( $\left.s_{P T \text { line }}\right)$ and after calculating $T_{o p}$, operating speed of PT vehicle $\left(v_{o p}\right)$ can be derived:

$v_{o p}=\frac{S_{P T l i n e}}{T_{o p}}$

Thus, $T_{o p}$ enables evaluation of PT performances on macro level. The total time spent at PT stops is a sum of dwell times elapsed at different PT stops of the same PT line:

$T_{d w}=\sum_{i=1}^{n} t_{d w_{i}}$

where $t_{d w_{i}}$ is the dwell time for PT stop $i$ and $n$ is the number of PT stops on PT line, [16], [22]. The total running time between PT stops is equal to:

$T_{r t}=\sum_{j=1}^{n-1} t_{r t_{j, j+1}}$

where $t_{r t_{j, j+1}}$ is the running time between two adjacent PT stops and $n$ is the number of PT stops, [16], [22]. The first PT stop is the origin terminal $A$ and $n$-th PT stop is the destination terminal $B$. The running time between two adjacent PT stops $\left(t_{r t_{j, j+1}}\right)$ is now decomposed into:

$t_{r t_{j, j+1}}=t_{d t_{j, j+1}}+\sum_{i=1}^{m} t_{i d_{i}}+\sum_{k} t_{\text {loss }}$

where $t_{d t_{j, j+1}}$ is the time which PT vehicle spends in motion between two adjacent PT stops (i.e. driving time) and $\sum_{i=1}^{m} t_{i d_{i}}$ is the total intersection delay which is caused at finite number of intersections $m$ between two adjacent PT stops $(j, j+1)$. Any additional loss of time (e.g. delay caused by mixed traffic conditions) is included in $\sum_{k} t_{\text {loss }}(k=0, \ldots, N$ where $N$ is the number of events which caused unplanned vehicle stopping). Note that expression $\sum_{i=1}^{m} t_{i d_{i}}$ can be equal to 0 in two cases; firstly, when PT vehicle passes through the intersection without stopping, and secondly, when there are no intersections between two adjacent PT stops.

The speed per segment $\left(v_{j, j+1}\right)$ is the distance travelled between two adjacent PT stops $\left(s_{j, j+1}\right)$ divided by $t_{r t_{j, j+1}}$ :

$v_{j, j+1}=\frac{s_{j, j+1}}{t_{r t_{j, j+1}}}$

This set of indicators $\left(t_{d w_{i}}, t_{r t_{j, j+1}}, t_{d t_{j, j+1}}, t_{i d_{i}}\right.$ and $\left.v_{j, j+1}\right)$ enables micro level evaluation of PT performances.

\section{SITE AND MEASUREMENT DESCRIPTION}

For the purpose of this paper measurements were conducted in the demonstration corridor Frankopanska Street - Savska Street in the City of Zagreb (depicted by solid black line in Figure 2). This corridor has been selected because it connects the historic city centre in the north of the corridor with multidirectional traffic junction in the southern part of the corridor and represents an important part of the city traffic network. PT vehicles travel in this corridor in both directions - northbound and southbound. The corridor is a $3.2 \mathrm{~km}$ long two-directional street with 12 signalized intersections (without PT priority system) and 9 PT stops in each direction of travel. There are two PT lines which travel through the entire corridor and six PT lines which partially pass through this corridor (depicted by dashed lines in Figure 2).

In front of most intersections in the corridor the car drivers are allowed to drive on the tramway rails in order to make a right turn. There are also marked yellow lines on the road for the PT vehicles, but car drivers often fail to obey them (especially during peak hours). Thus, traffic infrastructure is often shared between different transport modes. 


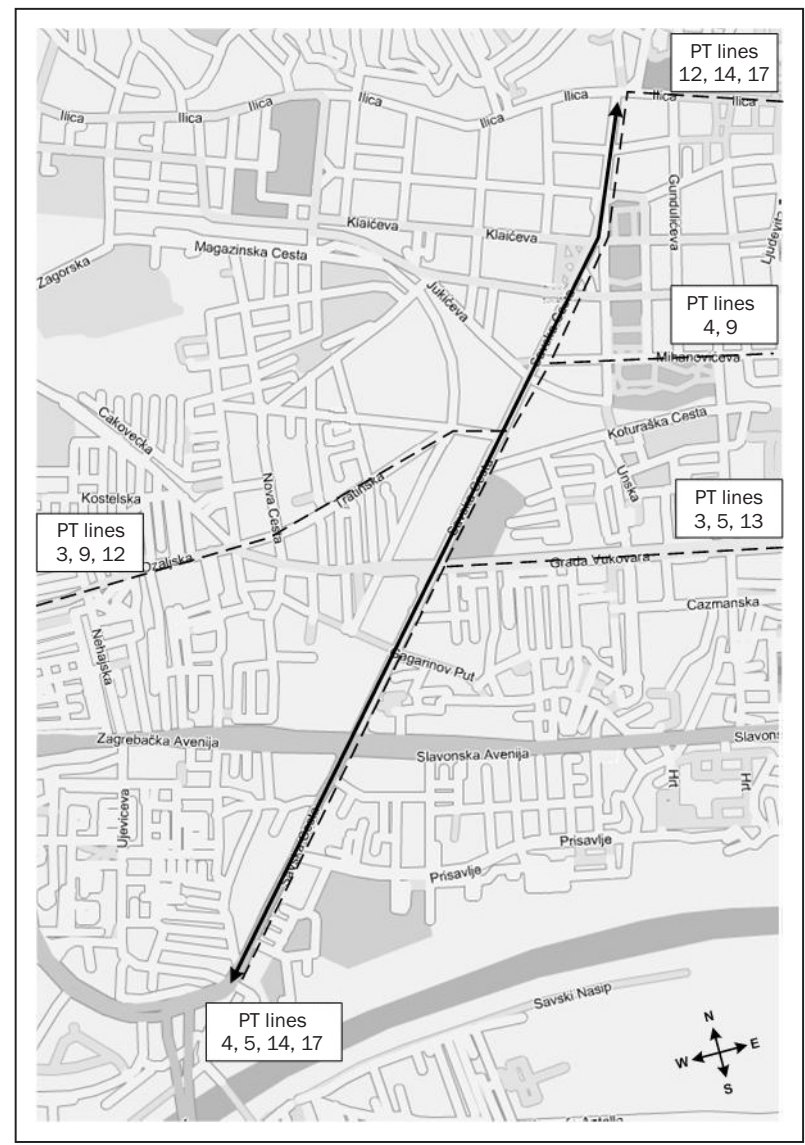

Figure 2 - Site map

To collect the data necessary for testing the proposed evaluation approach GPS receivers were installed in tramways. The receivers were set to record the vehicle speed and the position every second. The measurement lasted for one full week, each day from 6 a.m. to 10 p.m.. The coordinates of PT stops and intersections were also measured using GPS receivers.

We also checked whether the GPS error could influence the results. The GPS error was sometimes significant (e.g. 10-20m). The errors were corrected by data processing after the measurements.

\section{RESULTS}

\subsection{Dwell time}

Getting on and off PT vehicles is an integral part of all PT journeys. For the individual user the time taken to board and alight usually represents a small fraction of overall journey time, but the user may be adversely affected by the cumulative boarding and alighting times of other users, especially on longer journeys. This is more likely to hold for those PT modes where PT stops are more closely spaced (e.g. in the tramway or bus networks). Balcombe et al. in [20] emphasize the fact that longer boarding and alighting times lead to:

- longer average journey times (or, from the PT operator's perspective, operation times);

- greater variability of journey times;

- possible additional delays under highly congested operating conditions, since the following PT vehicles are unable to enter the stop area.

The amount of time which a PT vehicle spends at a specific PT stop is associated with the PT stop location and can vary during the day. As an example of those variations the results of the measurements of dwell times $\left(t_{d w_{i}}\right)$ for several PT stops in one PT vehicle journey have been presented (Table 2). In order to obtain dwell time results it was necessary to conduct the comparison of tramway speed and location with the location of PT stops. When specific PT stop is reached (geographical position) by tramway, speed equals $0 \mathrm{~km} / \mathrm{h}$ that represents a point in time when dwell time starts. The end of dwell time is identified when tramway speed becomes different from $0 \mathrm{~km} / \mathrm{h}$ (departure time). In this example two time intervals in a typical working day were analyzed. As it can be seen from the presented results, at some PT stops the tramway spends less than 15 seconds, which means that there are only few passengers boarding and alighting at those stations. The detailed analysis of dwell times on a bigger sample would be useful when making

Table 2 - Result of $t_{d w_{i}}$ measurements

\begin{tabular}{|c|c|c|c|c|}
\hline \multirow{2}{*}{ Name of the PT stop_sequence number } & \multicolumn{2}{|c|}{ First interval } & \multicolumn{2}{|c|}{ Second interval } \\
\hline & $t_{d w_{i}}$ & Departure time & $t_{d w_{i}}$ & Departure time \\
\hline Frankopanska_1 & $0: 00: 33$ & $14: 40: 38$ & $0: 00: 29$ & $16: 40: 50$ \\
\hline Trg_marš_Tita_2 & $0: 00: 58$ & $14: 43: 38$ & $0: 00: 27$ & $16: 42: 43$ \\
\hline Vodnikova_3 & $0: 00: 35$ & $14: 45: 13$ & $0: 00: 25$ & $16: 44: 03$ \\
\hline Stud_centar_4 & $0: 00: 15$ & $14: 47: 58$ & $0: 00: 26$ & $16: 47: 27$ \\
\hline Zagrepčanka_5 & $0: 00: 19$ & $14: 51: 29$ & $0: 00: 13$ & $16: 50: 23$ \\
\hline Učit_akademija_6 & $0: 00: 17$ & $14: 52: 51$ & $0: 00: 20$ & $16: 51: 59$ \\
\hline Vjesnik_7 & $0: 00: 12$ & $14: 54: 38$ & $0: 00: 12$ & $16: 53: 44$ \\
\hline Prisavlje_8 & $0: 00: 10$ & $14: 55: 43$ & $0: 00: 14$ & $16: 54: 59$ \\
\hline Veslačka_9 & 0:00:08 & $14: 56: 25$ & $0: 00: 12$ & $16: 55: 50$ \\
\hline$T_{d w}=$ & $0: 03: 27$ & & $0: 02: 58$ & \\
\hline
\end{tabular}


decisions about network restructuring. For example, if those stations with relatively short dwell time were removed from the network, the efficiency would be increased but, at the same time, accessibility would decrease by only a small number of users.

The fare collection methods also have a significant impact on average dwell times. The efficiency of different fare collection systems (conductor-operated, driver-operated, cash-free payment, off-vehicle ticketing and others) can be examined by conducting the dwell time analysis, [20]. Furthermore, the introduction of low-floored PT vehicles increases the accessibility and decreases the boarding and alighting times. The monetised value of dwell time can be used for justification of costs of new vehicles (i.e. cost-benefit analysis).

\subsection{Intersection delay}

PT vehicles travel in urban environment and their operational times may be significantly affected by the intersection delays experienced on their routes. In the cases when PT vehicles do not have priority at signalized intersections, $\sum_{i=1}^{m} t_{i d_{i}}$ can be a major part of $T_{o p}$. Understanding the relationship between variations of intersection delay and transport demand in a specific time period is crucial in the transport planning process, not only for the PT service operator but also for the local transport authority.

The results of $t_{i d_{i}}$ measurements for three selected intersections in the corridor are presented in Table 3. The arithmetic mean (AM) of $t_{i d_{i}}$ is expressed in its total value and by excluding $t_{i d_{i}}=0 \mathrm{~s}$ records. For each intersection high variations of $t_{i d_{i}}$ are present (see $\sigma_{i d_{i}}$ column), thus the Level of Service (LoS) significantly varies during the day. The LoS framework, defined in HCM 2000 [24], comprises six LoS classes for signalized intersections (A, B, C, D, E and $F$ with defined $t_{i d_{i}}$ intervals expressed in seconds $[0,10),[10,20),[20$, $35),[35,55),[55,80)$ and $[80,+\infty]$, respectively). Based on total $t_{i d_{j}}$ value, LoS classes are assigned in the last column of Table 3 .

The daily variations of average intersection delay (ID) for three selected intersections are depicted in Figure 3. For each $t_{i d_{i}}$ in the specific time period an LoS class has been assigned beneath the horizontal axes. The vertical grey lines in the diagrams correspond to the upper and lower limits of the assigned LoS class for the specific time period. This shows that, for instance, on the northbound approach of "Vjesnik_10" intersection (Figure $3 a$ ) $t_{i d_{10}}$ falls under class $C$ in the period from 6 p.m. to 8 p.m., but it is very close to the upper limit of that class, i.e. performance deteriorates towards class $D$.

By comparing the same intersection ("Zagrepčanka_8") it can be seen that the signal plans on that intersection and the transport demand cause lower performances in the period from 10 a.m. to 6 p.m. for the southbound PT traffic, compared to those experienced in the northbound direction (Figure 3b and Figure 3d). In other periods the situation is almost exactly the opposite.

With the $t_{i d_{i}}$ analysis the critical spots or segments in the traffic network, where significant time losses are present, may be identified. With this knowledge a strategy for implementation of priority measures can be defined more easily (e.g. Satiennam et al. in [25] elaborated the importance of intersection delay measurements in the development of priority system control logic). In their evaluation of the priority system impacts using the field observed traffic data the authors in [26] identified the intersection delay as an important indicator for PT priority system effectiveness.Figure 3 Daily variations of intersection delay at: a) Vjesnik_10northbound; b) Zagrepčanka_8-northbound; c) HT_7southbound; d) Zagrepčanka_8-southbound

The reduction of $t_{i d_{i}}$ and its variations in time must be one of the objectives of performance control. From the passengers' perspective the reduction of $t_{i d_{i}}$ leads to shorter travel times and increased service punctuality. For the operator the reduction means increased accuracy of timekeeping and increased reliability of real-time information.

From the economic perspective, the reduction of intersection delay reduces the PT vehicle operation time, thus it may be possible for the operator to deliver the same (or better) level of performance with fewer vehicles in operation. In other words, the costs can be reduced significantly. If we assign the monetised value of intersection delay to each individual passenger inside the PT vehicle, then $t_{i d_{i}}$ can be a major component of total transportation costs.

Table 3 - Intersection delay $\left(t_{i d_{i}}\right)$ results

\begin{tabular}{|c|c|c|c|c|c|c|c|c|c|c|}
\hline \multirow[b]{2}{*}{ Direction } & \multirow{2}{*}{$\begin{array}{l}\text { Name of the } \\
\text { intersection_se- } \\
\text { quence number }\end{array}$} & \multirow{2}{*}{$\begin{array}{c}\text { Total no. } \\
\text { of ap- } \\
\text { proaches }\end{array}$} & \multirow{2}{*}{$\begin{array}{c}\% \text { of } \\
t_{i d_{i}}=0\end{array}$} & \multirow{2}{*}{$\begin{array}{c}\% \text { of } \\
t_{i d_{i}} \neq 0\end{array}$} & \multicolumn{2}{|c|}{$t_{i d_{i}}(\mathrm{AM})$} & \multirow[b]{2}{*}{$\sigma_{i d_{i}}$} & \multirow{2}{*}{$\begin{array}{c}\text { MIN } \\
\left(t_{i d_{i}}=0\right. \\
\text { excluded })\end{array}$} & \multirow[b]{2}{*}{ MAX } & \multirow[b]{2}{*}{ LoS } \\
\hline & & & & & Total & $\begin{array}{c}t_{i d_{i}}=0 \\
\text { excluded }\end{array}$ & & & & \\
\hline \multirow{2}{*}{ Northbound } & Vjesnik_10 & 109 & 32.11 & 67.89 & 0:00:38 & $0: 00: 56$ & 0:00:39 & $0: 00: 15$ & $0: 04: 20$ & $\mathrm{D}$ \\
\hline & Zagrepčanka_8 & 109 & 8.26 & 91.74 & 0:01:17 & 0:01:24 & 0:00:45 & 0:00:13 & 0:03:44 & $\mathrm{E}$ \\
\hline \multirow{2}{*}{ Southbound } & HT_7 & 114 & 22.81 & 77.19 & 0:00:31 & $0: 00: 40$ & $0: 00: 21$ & $0: 00: 11$ & 0:01:08 & C \\
\hline & Zagrepčanka_8 & 110 & 11.82 & 88.18 & $0: 01: 20$ & $0: 01: 30$ & $0: 00: 49$ & $0: 00: 14$ & $0: 03: 17$ & $\mathrm{~F}$ \\
\hline
\end{tabular}



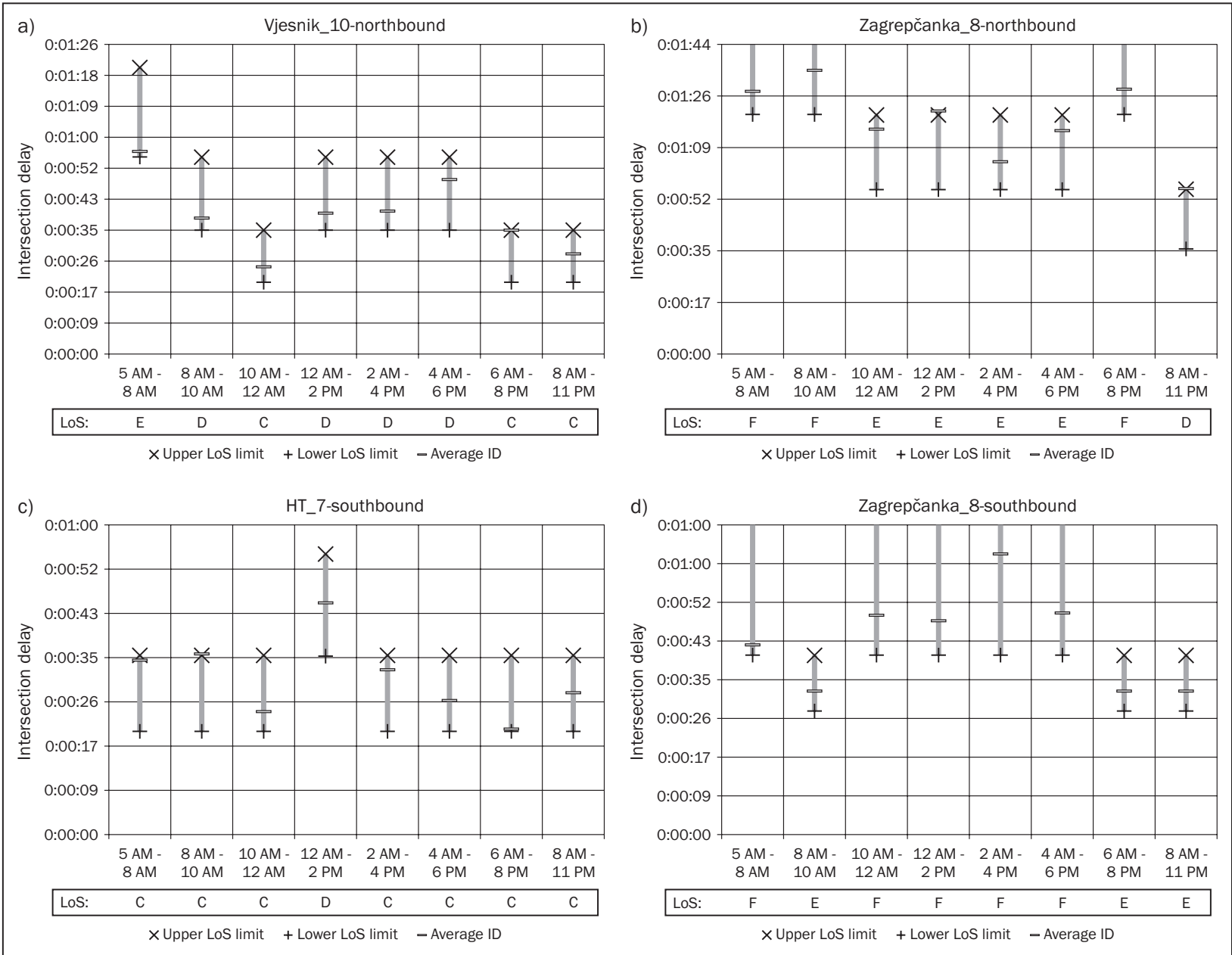

Figure 3 - Daily variations of intersection delay at: a) Vjesnik_10-northbound; b) Zagrepčanka_8-northbound; c) HT_7-southbound; d) Zagrepčanka_8-southbound

\subsection{Speed per segment and running time}

Vu and Khan in [27] state that the real-time arrival information of PT vehicles, provided at the PT stops, is viewed positively by passengers. They continue by confirming that the information itself represents a prediction which is based on vehicle position, average speed and running (travel) time on specific segment of the PT line, i.e. between adjacent PT stops. Thus, it may be useful to enhance the methodological basis for improving predictions. Specifically, data captured and communicated by intelligent systems are to be supplemented by reliable predictive running time. This can only be achieved by carrying out an extensive analysis

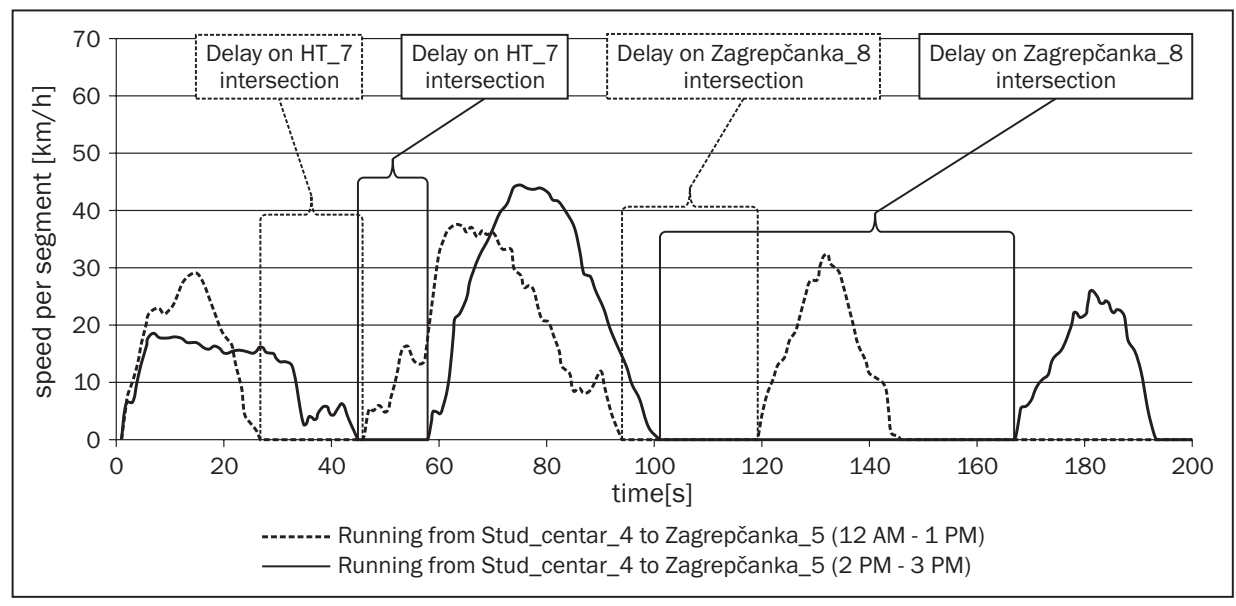

Figure 4 - Comparison of measured PT vehicle speeds between two adjacent stations 
Table 4 - Decomposition of running time $t_{r t_{j, j+1}}$

\begin{tabular}{||c|c|c|c|c|c|c|c||}
\hline \hline Time of running & $t_{d t_{j, j+1}}$ & $t_{i d_{1}}$ & $t_{i d_{2}}$ & $\sum_{i=1}^{2} t_{i d_{i}}$ & $\sum_{k} t_{l o s s_{k}}$ & $t_{r t_{j, j+1}}$ & $\bar{v}_{j, j+1}[\mathrm{~km} / \mathrm{h}]$ \\
\hline \hline 12 a.m. - 1 p.m. & $0: 01: 36$ & $0: 00: 21$ & $0: 00: 27$ & $0: 00: 48$ & $0: 00: 00$ & $0: 02: 24$ & 13.09 \\
\hline 2 a.m. - 3 p.m. & $0: 01: 49$ & $0: 00: 14$ & $0: 01: 08$ & $0: 01: 22$ & $0: 00: 00$ & $0: 03: 11$ & 10.83 \\
\hline
\end{tabular}

of speed and running time for different periods of day and for different PT lines.

As an example of this analysis Figure 4 shows the comparison of the measured PT vehicle speeds between two adjacent PT stops ("Stud_centar_4" and "Zagrepčanka_5”) during different time periods.

Speed trajectories depicted in Figure 4 are useful for examining the main reasons of deceleration and stopping. Slow motion with almost constant-speed trajectory in the beginning, for monitored PT vehicle in the period from 2 p.m. to 3 p.m., is the result of the occupied PT lane, i.e. mixed traffic conditions. In addition, this speed trajectory shows long delay at the second intersection ("Zagrepčanka_8") which is more than one minute (see Table 4). The time spent on waiting to move forward to the intersection is included in $t_{i d_{i}}$ because the length of intersection approach lane is defined by GPS measurement.

Transport infrastructure is shared in our demonstration corridor; thus $t_{r t_{j, j+1}}$ variations in peak and off-peak periods of the day are significant due to the transport demand characteristics. In these conditions and without thorough analysis of speed per segment $\left(\bar{v}_{j, j+1}\right)$ and running time $\left(t_{r t_{j, j+1}}\right)$ the reliability of arrival time predictions cannot be ensured.

\subsection{Operation time and operating speed}

Since the measurements were carried out in the predefined demonstration corridor, the operation time is considered as the time that elapses from the entering of a PT vehicle into the corridor to the exit from the corridor.

For example, for the time period between 4 p.m. and 5 p.m. and for both directions of travel, the performed PT vehicle operation times $\left(T_{o p}\right)$ are shown in Table 5. For northbound and southbound directions four and nine journeys of PT vehicles were recorded, respectively, in the abovementioned time period. The shaded cells in the table indicate the minimum values (recorded on Sunday) and the maximum values are written in bold text (for northbound and southbound directions maximums were recorded on Tuesday and Wednesday, respectively). From the data in Table 5 it is clear that in this period the PT vehicles travel faster when they are heading north and generally travel faster during weekends.
Table 5 - Operation time comparison

\begin{tabular}{||c|c||c|c||}
\hline \multicolumn{2}{|c||}{ Northbound } & \multicolumn{2}{c||}{ Southbound } \\
\hline Journey number & $T_{\text {op }}$ & Journey number & $T_{\text {op }}$ \\
\hline \hline 1 & $0: 14: 43$ & 1 & $0: 19: 16$ \\
\hline 2 & $0: 13: 28$ & 2 & $0: 15: 31$ \\
\hline 3 & $0: 15: 37$ & 3 & $0: 12: 22$ \\
\hline 4 & $0: 13: 08$ & 4 & $0: 19: 12$ \\
\hline & & 5 & $0: 19: 40$ \\
\hline & & 6 & $0: 17: 53$ \\
\hline & & 7 & $0: 19: 19$ \\
\hline & & 8 & $0: 13: 07$ \\
\hline & & 9 & $0: 13: 11$ \\
\hline
\end{tabular}

Figure 5 depicts the AM of the derived operating speeds in the demonstration corridor for different PT lines and each direction of travel. Depending on the direction of travel it is evident that significant differences of operating speed are present on every PT line. If PT line number 4 is excluded, it may be concluded that PT vehicles travel faster when they travel northbound (for some PT lines the difference is close to $50 \%$ ). This only confirms that a detailed micro level analysis is needed when searching for reasons of this discrepancy in the delivered performance.

Both of these two indicators (operation time and operating speed) are important in the economic efficiency analysis of the PT system (e.g. energy consumption analysis), fleet management and for determining timetables. Furthermore, the reliability and integration of timetables is the main precondition for multimodal interoperability, [6-7].

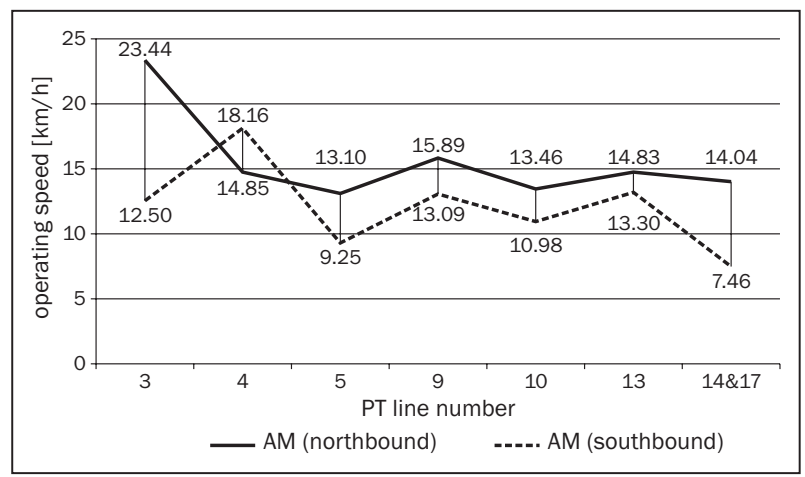

Figure 5 - Comparison of operating speeds for two directions of travel 


\section{DISCUSSION}

The paper shows that a two-level evaluation of public transport performances can be used by service operators and/or local transport authority in various stages of performance management and transport planning. The approach may be valuable when:

- evaluating the effects of PT priority measures, energy consumption, efficiency of fare collection systems, average journey times, average travel times on specific PT line segments etc.;

- conducting cost-benefit analysis;

- providing reliable real-time passenger information;

- introducing fleet management;

- implementing new services and systems.

Maybe the most beneficial output of the proposed evaluation approach is the ability to detect critical spots in the network, where performances deteriorate and there is an essential need for improvement. In our case, the macro level evaluation analysis showed that in the periods of high traffic load, PT vehicles travel faster when they are heading northwards in the corridor. The average $T_{o p}$ is 854 seconds for northbound and 997 seconds for southbound PT traffic. A significant difference between those two directions of travel is also demonstrated by the analysis of operating speeds where the difference is almost $4 \mathrm{~km} / \mathrm{h}$ in favour of northbound traffic, which is in line with previous results for $T_{o p}$. Two-level evaluation analysis enables detail investigation about the reasons for this discrepancy.

We already elaborated the problem of transport infrastructure sharing. The micro level analysis identifies precisely this as the major reason for PT performances deterioration. The analysis of intersection delay shows that "Zagrepčanka_8" intersection can be labelled as a corridor bottleneck for the PT. The average $t_{i d_{8}}$ for the southbound PT traffic, in the period from 4 p.m. to 5 p.m., is 99 seconds which is close to $10 \%$ of the total vehicle operation time for that period. Moreover, 13 intersection approaches in that period were recorded and there is not a single $t_{i d_{8}}=0$ s record. It is clear that PT vehicles experience difficulties in reaching that intersection due to the car queues, thus, maybe more restrictive measures toward car drivers should be considered.

Another reason for PT deterioration is space limitation at PT stops in the corridor. Most PT stops in the corridor do not have enough space for stopping of two PT vehicles at the same time. This represents a problem when PT stops are located directly after the intersection and two or more PT vehicles are approaching, [20]. The maximum recorded $t_{i d_{8}}$ of 4 minutes and 20 seconds on "Zagrepčanka_8" intersection demonstrates this issue. During that time, PT vehicle travelled only 89 meters and reached "Zagrepčanka_5" PT stop at the average speed of $1.23 \mathrm{~km} / \mathrm{h}$. PT vehicle arrival intervals at that PT stop should be reconsidered and any future efforts for the improvement should take into account the relocation of that stop.

The detailed two-level analysis also shows high daily variations of delivered performances in the corridor. The knowledge and understanding of those fluctuations can be essential for the synchronization of traffic signal plans and/or for introduction of PT priority measures. In his book Simpson recognizes this importance and states that PT priority can undoubtedly improve PT performance, but some questions need to be addressed first (e.g. what are the quantitative relationships between speed and reliability; will the improvements to PT services take place at certain times of the day; what will be the effects on the number of passengers, etc.), [28]. Variations of $t_{r t_{j, j+1}}, t_{d w_{i}}, t_{i d_{i}}$ and $\bar{v}_{j, j+1}$ shown in this paper can provide valuable input when making these decisions.

\section{CONCLUSION}

The two-level evaluation of PT performances can be an important means for PT operator and local transport authority, because it creates a valuable data source. It helps in reaching unambiguous conclusions about the reasons of possible performance deterioration by examining a PT line at two different levels. The higher, macro level is useful for overall determination of PT performances, energy consumption and costs; while the lower, micro level focuses on identifying critical segments or spots in the network.

Furthermore, a frequently asked question is how the presence or absence of quality of service management quantitatively affects the network performance (e.g. giving priority to PT vehicles). Even though it is easy to conclude that the presence of quality of service management improves the performance of network and guarantees the level of service, it is difficult to quantify the improvement. This is because it depends on a large number of input parameters, and there has been no known systematic study of how sensitivity of network performance depends on these parameters.

In customer satisfaction surveys the users of PT services usually respond rather negatively to high variations of PT vehicle arrival times, because they make their journey plans unreliable. Unreliable arrival times are caused by unpredictable variations of running time, dwell time, driving time and intersection delay in a specific period or on a specific segment of a PT line. It has been shown that micro level analysis can be used to determine and understand those variations. This knowledge helps PT operator in the process of defining timetables, but also increases the quality of service perceived by passengers, because accuracy of real-time information can be increased. 
Throughout this paper we elaborated the importance of quantifiable attributes of PT performance and our micro and macro level analysis. We now stress the issue of evidently present relation between the delivered performance and the perceived quality of PT service by PT users. In our future research we will concentrate on developing a model for prediction of user perception based on the delivered performance.

\section{ACKNOWLEDGMENTS}

This paper is inspired by the research undertaken in the CiViTAS ELAN project (FP7). We wish to thank all the project partners, especially Zagreb public transport company (ZET) for enabling us to conduct the measurements. We express a special gratitude to Professor Hrvoje Gold for his inspiring ideas for data collection and generous support.

MARKO MATULIN, dipl. ing.

E-mail: marko.matulin@fpz.hr

Dr. SC. ŠTEFICA MRVELJ

E-mail: mrveljs@fpz.hr

Dr. Sc. NIKO JELUŠIĆ

E-mail: niko.jelusic@fpz.hr

Sveučilište u Zagrebu, Fakultet prometnih znanosti

Vukelićeva 4, 10000 Zagreb, Hrvatska

\section{SAŽETAK}

\section{DVORAZINSKA EVALUACIJA PERFORMANSI JAVNOG GRADSKOG PRIJEVOZA}

Tema ovog rada je evaluacija performansi javnog gradskog prijevoza (JGP). U tu svrhu usmjereni smo na kvantitativne atribute performansi tramvajske mreže, te definiramo dvije razine evaluacije - analizu na mikro i makro razini. Dvorazinska analiza može biti upotrijebljena u rješavanju problema pojave višeznačnosti u zaključcima o performansama JGP-a. Višeznačnost se može pojaviti zbog nepotpunog skupa prikupljenih podataka, njihove pogrešne interpretacije, nepotpune analize ili zbog zanemarivanja nekih pozadinskih utjecaja. Za svaku razinu analize definiramo skup indikatora te ih matematički opisujemo. Izbor evaluacijskih indikatora temelji se na analizi mogućih događaja koji mogu nastupiti prilikom putovanja vozila JGP-a. Opisana je metodologija prikupljanja podataka, a dobiveni rezultati su prezentirani i komentirani. Na primjeru smo pokazali da dvorazinska analiza može biti ključna u procesu upravljanja performansama JGP-a i prometnom planiranju.

\section{KLUČNNE RIJEČI}

evaluacija, performanse javnog gradskog prijevoza, mikro i makro evaluacija, kvaliteta usluge

\section{LITERATURE}

[1] Fielding, G.J., Babitsky, T.T., Brenner, M.E.: Performance evaluation for bus transit, Transportation Research, Vol. 19, 1985, pp. 73-82
[2] Gomes, L.F.A.M.: Multicriteria ranking of urban transportation system alternatives, Journal of Advanced Transportation, Vol. 23, No. 1, 1989, pp. 43-52

[3] Egmond, P., Nijkamp, P., Vindigni, G.: A comparative analysis of the performance of urban public transport systems in Europe, Blackwell Publishing Ltd, Oxford, 2003

[4] Hirschhausen, C., Cullmann, A.: A nonparametric efficiency analysis of German public transport companies, Transportation Research Part E, Vol. 46, 2010, pp. 436-445

[5] Badami, M.G, Haider, M: An analysis of public bus transit performance in Indian cities, Transportation Research Part A, Vol. 41, 2007, pp. 961-981

[6] Buehler, R., Pucher, J.: Making public transport financially sustainable, Transport Policy, Vol. 18, 2011 (article in press), pp.126-138

[7] Wardman, M.: Public transport values of time, Transport Policy, Vol. 11, 2004, pp. 363-377

[8] Karlaftis, M.G., McCarthy, P.S.: Subsidy and public transit performance: A factor analytic approach, Transportation, Vol. 24, Kluwer Academic Publishers, 1997, pp. $253-270$

[9] Thompson, K., Schofield, P.: An investigation of the relationship between public transport performance and destination satisfaction, Journal of Transport Geography, Vol. 15, 2007, pp. 136-144

[10] Kordupleski, R.E., Rust, R.T., Zahorik, A.J.: Why improving quality doesn't improve quality (or whatever happened to marketing?), California Management Review, Vol. 3, No. 35, 1993, pp. 82-95.

[11] Harrison, S., Henderson, G., Humphreys, E., Smyth, A.: Quality bus corridors and green routes: can they achieve a public perception of 'permanence' of bus services?, Public Transport Planning and Operations. Proceedings of Seminar F, European Transport Conference, PTRC, London, 1998, pp. 225-236.

[12] Pullen, W.: The Measurement of the quality of local bus services with respect to the effects of bus deregulation in Scotland, Ph.D. thesis, University of Newcastle upon Tyne, Newcastle, 1991

[13] Prioni, P., Hensher, D.A.: Measuring service quality in scheduled bus services, Journal of Public Transportation, Vol. 2, No. 3, 2000, pp. 51-74

[14] Wagener, N.: Service quality in public passenger transport (EN 13816), Wagner \& Herbst, available at: http:// www.wagener-herbst.com

[15] Yeh, C.H., Deng, H., Chang, Y.H.: Fuzzy multicriteria analysis for performance evaluation of bus companies, European Journal of Operational Research, Vol. 126, 2000, pp. 459-473

[16] Štefančić, G.: Tehnologija gradskog prometa 1, Sveučilište u Zagrebu, Fakultet prometnih znanosti, Zagreb, 2008

[17] Khisty, C.J., Lall, B.K.: Transportation engineering - An introduction ( $3^{\text {rd }}$ Edition), Prentice Hall, New Jersey, 2002

[18] Sun, H., Si, B., Wu, J.: Combined model for flow assignment and mode split in two-modes traffic network, J Transpn Sys Eng \& IT, Vol. 8, No. 4, 2008, pp. 77-82

[19] Zhu, H.B.: Numerical study of urban traffic flow with dedicated bus lane and intermittent bus lane, Physica A, Vol. 389, 2010, pp. 3134-3139 
[20] Balcombe, R., Mackett, R., Paulley, N., Preston, J., Shires, J., Titheridge, H., Wardman, M., White, P.: The demand for public transport: a practical guide, TRL Report, TRL 593, Crowthorne, 2004

[21] Engels, D., Kontić, B., Matulin, M., Mrvelj, Š., Cauwenberge, B., Valkova, J., Vilarinho, C., Pedro Tavares, J., Salens, M., Wefering, F., Zwerts, E., De Vos, E.: Final evaluation plan, CiViTAS ELAN Deliverable No. 12.1, 2009, available at: http://www.civitas-initiative.org

[22] Matulin, M., Mrvelj, Š., Gold, H.: Evaluating the public transport priority system - Identifying background data impact, Proceedings of the 17th ITS World Congress, Busan, 2010

[23] Mrvelj, Š., Matulin, M., Jelušić, N.: Public transport priority system: Impact on quality of service, Proceedings of the 21st Central European Conference on Information and Intelligent Systems, Varaždin, 2010, pp. 457462
[24] Transport Research Board: Highway capacity manual 2000, TRB, National Research Council, 2000

[25] Satiennam, T., Muroi, T., Fukuda, A., Jansuwan, S.: An enhanced public transport priority system for two-lane arterials with nearside bus stops, Proceedings of the Eastern Asia Society for Transportation Studies, Vol. 5, Tokyo, 2005, pp. 1309-1321

[26] Wang, Y., Hallenbeck, M., Zheng, J., Zhang, G., Ma, X., Corey, J.: Comprehensive evaluation of transit signal priority system impacts using field observed traffic data, Transportation Northwest Regional Center X, University of Washington, 2008

[27] Vu, N.H., Khan, A.M.: Bus running time prediction using a statistical pattern recognition technique, Transportation Planning and Technology, Vol. 33, No. 7, 2010

[28] Simpson, B.J.: Urban public transport today, E \& FN Spon, London, 2004 